\title{
In Vitro Assays: Friends or Foes of Cell-Penetrating Peptides
}

\author{
Jinsha Liu and Sepideh Afshar* \\ Protein Engineering, Lilly Biotechnology Center, Eli Lilly and Company, San Diego, CA 92121, USA; \\ liu_jinsha@lilly.com \\ * Correspondence: afshar_sepideh@lilly.com
}

Received: 11 June 2020; Accepted: 1 July 2020; Published: 2 July 2020

\begin{abstract}
The cell membrane is a complex and highly regulated system that is composed of lipid bilayer and proteins. One of the main functions of the cell membrane is the regulation of cell entry. Cell-penetrating peptides (CPPs) are defined as peptides that can cross the plasma membrane and deliver their cargo inside the cell. The uptake of a peptide is determined by its sequence and biophysicochemical properties. At the same time, the uptake mechanism and efficiency are shown to be dependent on local peptide concentration, cell membrane lipid composition, characteristics of the cargo, and experimental methodology, suggesting that a highly efficient CPP in one system might not be as productive in another. To better understand the dependence of CPPs on the experimental system, we present a review of the in vitro assays that have been employed in the literature to evaluate CPPs and CPP-cargos. Our comprehensive review suggests that utilization of orthogonal assays will be more effective for deciphering the true ability of CPPs to translocate through the membrane and enter the cell cytoplasm.
\end{abstract}

Keywords: cell-penetrating peptides (CPPs); in vitro assays; penetration; internalization; translocation; plasma membrane; lipid vesicle membrane

\section{Introduction}

The cell membrane is an asymmetric phospholipid bilayer with aminophospholipids mostly at the inner (cytoplasmic) leaflet and cholinephospholipids preferentially at outer (exoplasmic) side [1,2]. Proteins that are embedded in the lipid bilayer can facilitate signal transduction or function as transporters, enzymes, or joining proteins. The key function of the cell membrane is to create a physiological barrier allowing compartmentalization and to tightly regulate cell entry. As a result, exogenous compounds including therapeutic peptides, antibodies, siRNA, and nanoparticles cannot easily access the inside of the cell that harbors $60-70 \%$ of the human proteome [3]. To overcome this challenge, cell-penetrating peptides (CPPs) are exploited as versatile delivery vehicles to cross cell membrane.

CPPs are cationic, amphipathic, or hydrophobic peptides of 5-39 amino acid in length $[4,5]$. The most widely studied CPPs are truncated version (Tat ${ }_{48-60}$ and Tat $_{49-57}$ ) of trans-activator of transcription (Tat) protein from HIV-1 [6-9] and penetratin (16 residues) from the homeodomain of Drosophila antennapedia [10-12]. Energy-independent direct translocation and energy-dependent endocytosis are generally accepted as the main internalization mechanisms of CPPs [13-15]. Nevertheless, the mechanisms of CPP-cargo cell entry have remained controversial. One point of view is that the same CPP can employ multiple cell entry mechanisms depending on the peptide local concentration, avidity, cell membrane lipid composition, and cell type [16-18]. However, alterations in physiochemical properties of a peptide, even as slight as conjugation to a dye, has been shown to influence the mechanisms and efficiency of the uptake [19]. This has led to the second point 
of view that $\mathrm{CPP}$ and cargo are one unit where the physiochemical properties of the CPP, the cargo (fluorescence dye or any functional moiety), and their combination can influence delivery pathways and their final destination.

Among over ten thousand CPPs described in the literature, only a few Tat-based therapeutic peptides have reached the advanced stages of clinical trials $[8,9,20]$. Utilization of CPPs as "trojan horses" has been limited due to their entrapment in the endosomes upon cell entry [21-23]. This limitation promoted a tremendous effort to optimize the potency of CPP-cargos and the discovery of new CPPs with greater innate and specific delivery performance inside the cell [23-26]. However, difficulties in discriminating cytoplasmic uptake from endosomally trapped molecules have hampered the identification of true CPPs for therapeutic purposes. These difficulties have also limited our understanding of the physiochemical parameters that determine final intercellular localization of CPP-cargos. Therefore, extensive attempts have been made to develop cell- and lipid vesicle-based assays that can determine cell entry and cytoplasmic localization. These assays that include intracellular fluorescence detection by microscopy and/or flow cytometry, transcriptional reporter system, and mass spectrometry are discussed in this review [4]. Critical factors in assay development, such as material generation and sensitivity of detection should be also taken into careful consideration. In this review, in vitro cell-based assays and an in-depth review of recent strategies to utilize lipid vesicles for study of CPPs are discussed. Advantages and limitations of each approach are also summarized. Table 1 presents an overview of CPPs mentioned in this review paper.

Table 1. List of CPPs used in various assays.

\begin{tabular}{|c|c|c|c|c|c|c|}
\hline CPP & Sequence & Length & MW & PI & Charge at $\mathrm{pH} 7$ & Ref. \\
\hline Penetratin & RQIKIWFQNRRMKWKK & 16 & 2246.76 & 12.8 & 6.94 & [27-36] \\
\hline Tat ${ }_{(48-60)}$ & GRKKRRQRRRPQ & 12 & 1621.92 & 13.18 & 7.94 & \multirow{2}{*}[23,28,29,36-42]{} \\
\hline Tat $(49-57)$ & RKKRRQRRR & 9 & 1339.62 & 13.18 & 7.94 & \\
\hline Transportan & GWTLNSAGYLLGKINLKALAALAKKIL & 27 & 2841.48 & 10.7 & 3.94 & {$[28,36]$} \\
\hline $\begin{array}{c}\text { MAP } \\
\text { (KLAL) }\end{array}$ & KLALKLALKALKAALKLA & 18 & 1877.47 & 11.14 & 4.94 & {$[28,36]$} \\
\hline R8K & RRMKWKKK & 8 & 1160.5 & 12.52 & 5.94 & [30] \\
\hline $8 \mathrm{~K}$ & KKKKKКKK & 8 & 1043.41 & 11.39 & 7.94 & [38] \\
\hline $8 \mathrm{R}$ & RRRRRRRR & 8 & 1267.52 & 13.33 & 7.94 & [43] \\
\hline 9R & RRRRRRRRR & 9 & 1423.7 & 13.38 & 8.94 & {$[29,36,42,44,45]$} \\
\hline Ypep & YTFGLKTSFNVQ & 12 & 1404.59 & 9.19 & 0.94 & [46] \\
\hline MPG & GALFLGFLGAAGSTMGAWSQPKKKRKV & 27 & 2807.36 & 11.85 & 4.94 & {$[47,48]$} \\
\hline Pep-1 & KETWWETWWTEWSQPKKKRKV & 21 & 2848.26 & 10.36 & 2.94 & [48] \\
\hline $\mathrm{P} \beta$ & GALFLGFLGAAGSTMGAWSQPKKKRKV & 27 & 2807.36 & 11.85 & 4.94 & [48] \\
\hline TP2 & PLIYLRLLRGQWC & 13 & 1630.01 & 9.48 & 1.88 & [49] \\
\hline TP10 & AGYLLGKINLKALAALAKKIL & 21 & 2182.76 & 10.7 & 3.94 & {$[36,45]$} \\
\hline
\end{tabular}

\section{Cell-Based In Vitro Assays}

Cellular internalization of the CPP can be detected using three strategies where (1) CPP is conjugated to a tag or a functional moiety, (2) mammalian cells are engineered to express a specific protein that is used to detect cytoplasmically localized CPP, or (3) the combination of first and second approaches is utilized. In this section, intracellular detection of fluorescence by microscopy and flow cytometry, protein complementation, phenotypic alteration induced by a functional group, and transcriptional reporter system are discussed. Gene delivery approaches are also examined to highlight the recent advancement in assay development. The main focus of all these assays is to distinguish CPPs that enter cytoplasmic domain of the cell from the ones that are entrapped in the endosomes.

\subsection{CPPs as Vehicles of Biotin or Fluorescent Entities}

Laser scanning confocal fluorescence microscopy and flow cytometry have been heavily used to quantify cellular uptake of fluorochrome or biotin conjugated CPPs [50-53]. Fluorescent tags and biotin can be conjugated by the standard N-hydroxysuccinimide (NHS), isothiocyanate, or click 
chemistry to peptides [54-56]. One limitation of direct conjugation such as NHS is the inability to control distribution and quantity of dyes on a single peptide. Thus, the high intensity of fluorescence inside the cell may be misleading and might be due to low concentration of CPP with high amount of conjugated dye. To improve this, site-specific labeling methods were developed. For example, phage coat protein such as PIII or PVIII, was engineered to display a sequence containing LPETG, a recognition motif for prokaryotic enzyme Sortase. Sortase cleaves after a Thr residue and forms an intermediate with the phage, which is resolved upon covalent bond formation with $\alpha$-amine of a fluorophore labeled poly-glycine peptide. As the result, a site-specific fluorophore labeling is achieved [57]. Such site-specific labeling techniques can be employed in CPP studies to improve intracellular uptake quantification.

Assays that use dye-labeled peptides with quenching models were revised to reduce non-specific interaction. For example, highly fluorescent 7-nitrobenz-2-oxo-1,3-diazol (NBD) fluorophore was used to label CPPs such as penetratin. NBD is irreversibly inactivated in to nonfluorescent 7-amino-2,1,3-benzoxadiazol-4-yl in the presence of dithionite [58]. Internalization of NBD-penetratin was tested in human leukemia $\mathrm{K} 562$ cells at either $37^{\circ} \mathrm{C}$ or $4{ }^{\circ} \mathrm{C}$, followed by a treatment of dithionite at $4{ }^{\circ} \mathrm{C}$. Any portion of the CPP that was not internalized (extracellular and membrane bound) was inactivated upon addition of the cell impermeable dithionite at $4{ }^{\circ} \mathrm{C}$, hence fluorescence was only due to the internalized peptide [27]. In a different study, Hallbrink and colleagues labeled the CPP with a fluorescence quencher 3-nitrotyrosine (CPP-nitroY-C) and coupled it to a non-penetrating cargo (LKANL) bearing the 2-amino benzoic acid (Abz) fluorophore (Abz-C-LKANL) via a disulfide bond. Penetratin, transportan, Tat, or MAP (KLAL) were used as CPPs. The cellular uptake of Abz-C-LKANL was indicated as an increase in fluorescence intensity when the disulfide bond in the construct (CPP-quencher-S-S-cargo fluorophore) was reduced in the intracellular domain due to the reducing environment [28]. The internalization assay was performed in 96-well plates with application of peptide complex at concentrations ranging 0.1-10 $\mu \mathrm{M}$ in Bowes human melanoma cells. Dithiothreitol (DTT) was added to the wells to reduce external peptide-cargo and the overall fluorescence intensity was used as the max value. The internalized CPP-S-S-cargo was measured proportionally as fractions to the total amount of constructs added. Fluorophore-quencher pair such as TAMRA-QSY7 [59] has also been employed to monitor polypeptides entry into endosomal vesicles where activated fluorescence, caused by dequenching, was measured. Considering the low $\mathrm{pH}$ and reducing environment of the endosomal and lysosomal vesicles and the fact that fluorescence intensity was measured by a spectrometer in these studies, final destination of CPP-cargo remains undefined and additional work is needed to verify endosomal escape of CPPs.

The use of fluorescent tags, although the primary method to detect peptide and peptide-cargo inside the cells, has many limitations. Direct dye-attachment may create artifacts due to degradation and self-quenching in low $\mathrm{pH}$ environment such as endocytic vesicles [17]. The fluorescent dyes and biotin, conjugated to CPPs, do not share similar properties as therapeutic cargos. Therefore, effectiveness of CPPs as vehicles of therapeutic cargos remains somewhat unclear [60]. Detection of the internalized CPPs by confocal imaging has its own limitations. First, certain methods of cell fixation might cause artificial signal or re-localization/redistribution of the fluorescent dye [61], if immunostaining is conducted on fixed cells. Second, the microscopic detection is strongly dependent on the accessibility of antibody to the target and/or streptavidin to biotin inside the cell. Measurements of fluorescent intensity might be influenced by the use of automatic or manual intensity scaling, causing a misleading signal of uptake. The drawbacks of cell fixation and antibody accessibility can be overcome by using live cell imaging to detect and monitor the uptake of the fluorescence tagged CPP. In order to differentiate cytosolic entry of CPP-cargo, fluorescent cell-permeable trackers are needed to outline the cytosolic domain from other organelles. This approach requires a careful evaluation to avoid nonspecific background signals, physiological artifacts, cytotoxicity, and most importantly, any interference between the cell-permeable trackers and CPP-cargo entry. 
Continuous innovation in the field of protein chemistry can have a positive impact in the CPP-related research. Fluorescent proteins with photoswitching behavior in acidic compartments compared to the cytosol have been used to study autophagic flux and endocytosis in transfected mammalian cells. Ratiometric response induced by the $\mathrm{pH}$ sensitive fluorescent proteins can be measured in different cellular compartments by fluorescent microscopy and/or flow cytometry. For example, $\mathrm{pH}$-stable enhanced GFP (eGFP) was fused to a pH-sensitive RFP $[62,63]$ to detect protein levels in various cellular compartments. Similarly, fusion of a $\mathrm{pH}$-stable cyan fluorescent protein (FP) variant mTurquoise2 to a highly $\mathrm{pH}$-sensitive enhanced yellow fluorescent protein eYFP (pH-lemon) [64] had enabled protein quantification in different compartments. In acidic cellular compartments such as endosomes and lysosomes, yellow fluorescence would be reduced while the cyan fluorescence would be enhanced due to the reduced Forster resonance energy transfer (FRET) efficiency. Thus far, the $\mathrm{pH}$ sensitive probes have not been employed as cargos of CPPs and their function in the context of CPP is yet to be determined.

\subsection{CPPs as Vehicles of Split Protein for Fragment Complementation}

Few functional proteins can be dissected into two inactive fragments. These conditional split-protein assembly was developed with ubiquitin, dihydrofolate reductase (DHFR), $\beta$-lactamase, TEV protease, chorismite, thymidine kinase, firefly luciferase, and green fluorescence protein (GFP) [65]. Fluorescence or luminescence complementation is the most common strategy to reconstitute a functional protein upon spatial proximity of the two split parts.

GFP and its variants such as eYFP have been extensively optimized to enhance solubility, reconstitution efficiency, and to reduce background signals $[66,67]$. In the natural state, the proteins are assembled into a barrel shaped structure composed of 11 strands of $\beta$-sheets that allows peptidyl backbone cyclization and formation of a fluorescence chromophore. GFP can be split between strand seventh and eighth [68] or strand tenth and eleventh $[67,69,70]$. Similarly, eYFP can be split between the seventh and the eighth [71,72], eighth and the ninth [73,74], or tenth and the eleventh $\beta$-sheet strands $[75,76]$. Co-incubation of the two fragments of GFP in trans results in efficient reconstitution of GFP chromophore bond and restores GFP fluorescence. Smaller complementary fragments, such as strand 11 (s11) of the GFP have been used as cargos of CPPs while the larger fragments were engineered for cytoplasmic expression in mammalian cells (Figure 1A). The split assembly ensures that complementation occurs only when the CPP-GFPs11 enters the cytoplasmic area to form the full length GFP molecule [77-79]. The split GFP assay offers several advantages; it confirms true cytoplasmic localization through GFP complementation fluorescence; cytoplasmic entry can be monitored in real-time and in a quantitative manner by flow cytometry, and it can easily be adapted to a high-throughput assay format. Sensitivity of the assay can be influenced by the expression level of GFPs1-10 fragment in the cytosol. As a result, signal threshold in individual cells caused by GFP fluorescence depends on the number of CPP-cargo delivered inside the cells and the expression level of GFPs1-10 fragment. 


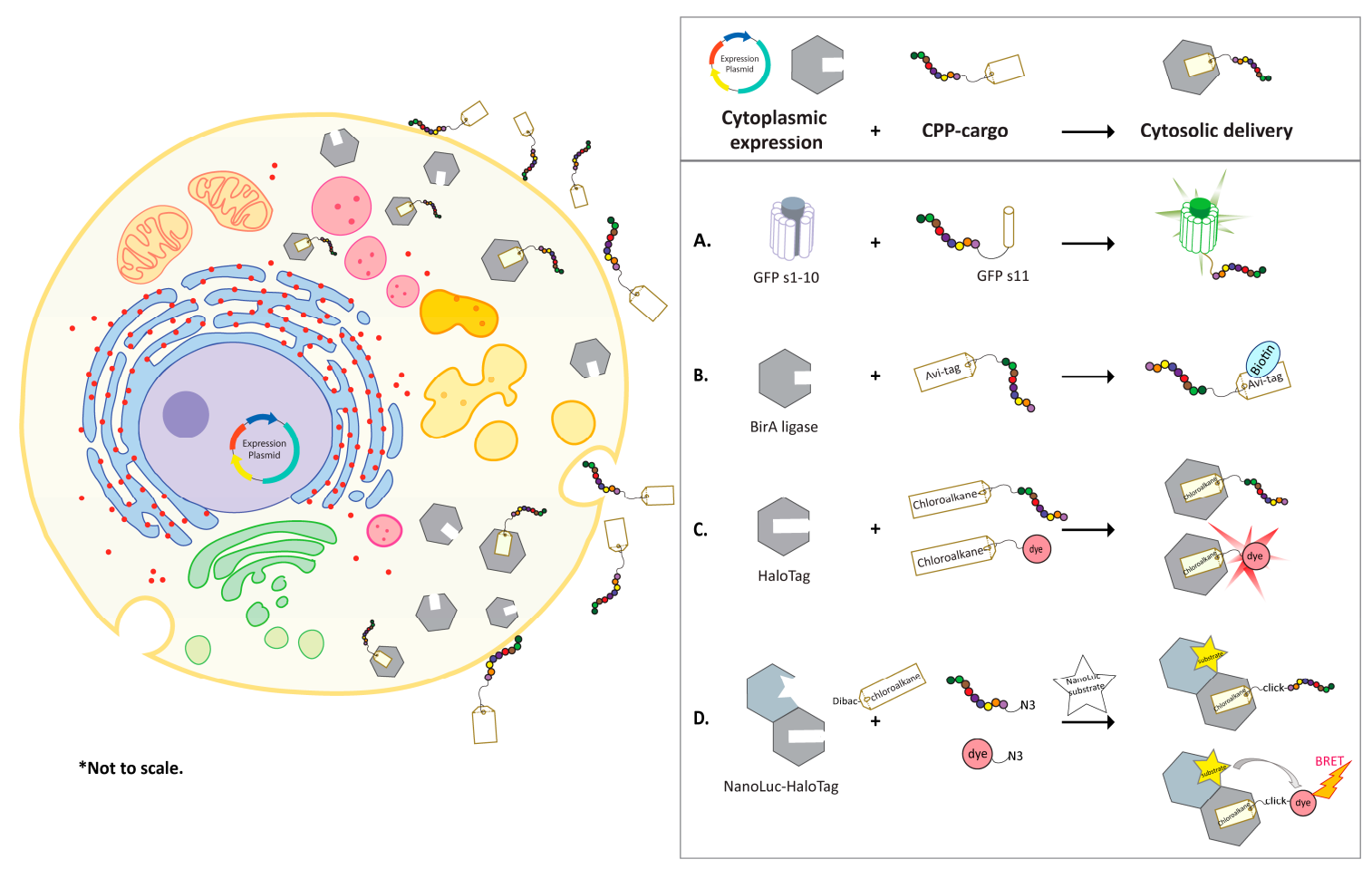

Figure 1. Schematic of CPPs as vehicles of split protein and functional tags. Mammalian cells are engineered to express a specific protein in cytoplasmic domain. The cargo delivery is facilitated by CPP and detected in cytoplasmic by (A) Split-GFP complementation assay, (B) BirA-based cytosolic delivery assay, (C) Chloroalkane penetration assay, and (D) NanoClick assay. Dibac: Dibenzoazacyclooctyne; N3: azide-modification (click, click-reaction by Dibac and azide functionalized molecules).

\subsection{CPPs as Vehicles of Functional Tags}

Cytosolic localization of a CPP can be validated if its cargo undergoes an enzymatic reaction that occurs solely in the cytoplasm. In this approach, substrate conversion and/or product formation should be easily detected. Utilization of multi-functional tags (SNAP-, CLIP- and ACP-tags) [80-82] that have been used for labeling soluble or cell surface proteins has been limited in CPP evaluation due to their large size and bulky structure. On the other hand, few known short tags that act as a specific enzyme substrate have poor efficiency. For example, serine in the 11-residue peptide "ybbR tag" (DSLEFIASKLA) was identified as a substrate for Sfp phosphopantetheinyl transferase [83] with only 17\% labeling efficiency [84]. Characteristics of the tag, enzymatic efficacy, substrate specificity, and feasibility of labeling inside mammalian cells is consequential in this approach. This section will describe three technologies for evaluation of CPPs that have escaped endosomal entrapment. All technologies exploit an enzymatic reaction that occurs in the cytosol.

Verdurmen and colleagues developed a biotin ligase-based assay to measure cytosolic delivery [85-87]. Biotin ligase (BirA) biotinylates lysine residue in the Avi-tag (GLNDIFEAQKIEWHE) [88]. Various cells lines, such as SKBR3, MCF7, HT29, and HEK293 were engineered to stably overexpress E. coli derived BirA in the cytosol [89] (Figure 1B). Avi- and HA-tagged CPPs carrying eGFP (Avi-HA-CPP-eGFP) were added to the BirA expressing cells. Cells were then lysed, and the cytosolic delivery was quantified by western blots using fluorescently labeled streptavidin relative to the uptake of the HA tag. The design was improved by Hoffmann and co-workers with an additional step of adding sodium pyrophosphate (PPi) to stop the BirA reaction prior to cell lysis and streptavidin capture. The platform was applied in discovery of novel CPPs from a random peptide library displayed on T7 phage [90]. The cytoplasmic biotinylation differentiated CPPs from the peptides that did not internalize or were trapped in the endosomes. As a result of ten independent selection campaigns using different cell lines, thousands of CPPs were identified. These novel CPPs were 
evaluated in cell-based screening assays such as GFP complementation assay. Hits were optimized for potency and half-life extension [90].

The second technology utilizes HaloTag to interrogate cytosolic localization in chloroalkane penetration assay (CAPA) [29,91]. Halo-tag in the cytosol of cells can be covalently conjugated to any chloroalkane conjugated CPPs, if the CPP-cargo has found its way to the cytosol [92-94]. This is followed by the addition of a chloroalkane-dye for binding to the unreacted free HaloTag. The dye intensity reversely correlates to the cytosolic CPP levels and could be quantified by flow cytometry (Figure 1C). Chloroalkane tagged Tat, penetratin and nona-arginine (9R) showed concentration-dependent cytosolic localization after 4 hours with $\mathrm{CP}_{50}$ values at $3.1,0.82$, and $0.3 \mu \mathrm{M}$, respectively. $\mathrm{CP}_{50}$ was defined as the concentration at which $50 \%$ cell penetration was observed under assay conditions. The $\mathrm{CP}_{50}$ values were comparable to values obtained for the same CPPs in the assay where MALDI-MS was used to detect internalized peptides [50].

The third strategy, NanoClick, was developed by combining the HaloTag technology and in-cell copper-free Click chemistry. The cytosolic uptake of azide-tagged CPPs was monitored quantitively by a NanoBRET signal in cells [95]. In this assay, Dibenzoazacyclooctyne-chloroalkane (DiBac-CA) was applied to cells expressing NanoLuc-HaloTag in the cytoplasmic domain. This was followed by application of azide-modified CPPs to anchor the intracellular HaloTag. Subsequent introduction of azido-dye and NanoLuc substrate to cells allowed the detection of a BRET signal that reversely correlated with the concentration of the azide-CPP in the cytosol (Figure 1D).

All strategies are great approaches to detect CPPs that are localized to cell cytoplasm. Special attention should be paid to ensure that internalization and cytoplasmic localization are due to the CPP and not the tag, as tags may also lead to potential artifact due to degradation. Different linkers, connecting CPP to its cargo, may also have an effect on the molecule penetration. Both assays, mentioned above, require cell line engineering to overexpress enzymatic proteins in the cytosol. Hence, the sensitivity of the assays might be limited by protein expression level. Moreover, transfection might be challenging for some cell lines of interest, such as primary cells.

\subsection{CPPs as Vehicles of Functional Groups to Enable Phenotypic Readouts}

Various functional peptides or proteins that could attenuate protein-protein or enzyme-substrate interactions were fused to the classical CPPs, particularly Tat and penetratin, to evaluate their potential as vehicles for intracellular delivery [96]. The phenotypic changes induced by CPP-cargo internalization can be categorized as gene activation or blocking, cellular cytotoxicity or protection, or simply fluorescence/luminescence emission. Nearly three decades ago, Fawell and co-workers chemically cross-linked Tat peptides to cell-impermeable entities such as $\beta$-galactosidase, horseradish peroxidase (HRP), RNase A, and domain III of Pseudomonas exotoxin A (PE). The intracellular uptake of Tat-facilitated $\beta$-galactosidase and HRP were measured colorimetrically by histological staining, and the uptake of Tat-RNase A and -PE were evaluated by the induced cytotoxicity in HeLa cells [97]. In this section, we discuss a selected number of functional groups that can be used as a cargo to allow specific readouts in the cell-based assays. Smaller size cargos are discussed first.

Apoptosis induced by the cargo is the most commonly used readout to evaluate CPPs. A synthetic 14-amino acid pro-apoptotic peptide KLAKLAKKLAKLAK (KLAKLAK) $)_{2}$ was shown to disrupt the mitochondria membrane at $10 \mu \mathrm{M}$ and cause cytotoxicity. This cationic peptide was fused to peptide CNGRC or RGD-4C (ACDCRGDCFC) to facilitate tumor cell entry [98,99]. A similar approach was carried out by Chen and collaborators, where two octa-peptides, PVKRRLDL and PVKRRLFG derived from E2F1 cell-cycle regulatory transcription factor family, were fused to Tat or penetratin. Both peptides were shown to block phosphorylation of E2F by cyclin/cdk2. Internalization of the peptides, facilitated by fusion to Tat or penetratin, resulted in deregulation of E2F, inhibition of cdk2, and cellular cytotoxicity in U2OS osteosarcoma and MDA-MB-435 cancer cells [37].

Inhibition of intracellular phosphorylation, as the result of CPP-cargo cell entry has served as a frequent readout. The eleven residue STAT1 binding peptide derived from measles virus V 
protein $(\mathrm{MV}-\mathrm{V})$ with the sequence YHVYDHSGEAV $\left(\mathrm{MV}-\mathrm{V}_{110-120}\right)$ was reported by Caignard and co-workers. The peptide was fused to Tat and octa-lysine (8K) for intracellular delivery to inhibit STAT1 phosphorylation [38]. When localized to cytoplasm of target cells, both Tat-MV- $\mathrm{V}_{110-120}$ and $8 \mathrm{~K}-\mathrm{MV}-\mathrm{V}_{110-120}$ were able to block type I interferons signaling pathway by approximately $40 \%$. Peptide-based STAT3 inhibitors are also reported $[100,101]$. The inhibitory phospho-peptides (PYLKTK and YLPQTV, phosphorylation on Y) bind to the SH2 domain of STAT3 and block dimerization, however, low potency (mM concentration) have limited their further use. Kim and colleagues identified a new STAT3 binding peptide with the sequence HGFQWPG(SWTWENGKWTWK)GAYQFLK. Fusion of this peptide to the N-terminus of 9R [44] resulted in reduced STAT3 phosphorylation in a DNA-binding assay and suppressed cell viability and proliferation in cancer cells. Alternatively, it was shown that cells could be rescued from apoptosis by CPP fusion to survival peptides. For example, C-Jun N-terminal kinase (JNK) binding peptide (RPKRPTTLNLFPQVPRSQDT) when fused to Tat, referred as D-JNK-1, protected $\beta$ TC-3 cells from stress-induced apoptosis [39]. D-JNK-1 blocked the phosphorylation of c-Jun activation domain in the cytoplasm, prevented the formation of transcription complexes, and inhibited cell death in $\beta$ - and hair-cells $[39,40]$.

An enzymatic assay was developed to assess cytosolic entry of ubiquitin-PEP-Alexa Fluor 594 conjugated to the C-terminus of Tat. Cytoplasmic deubiquitinating enzymes (DUBs) act on Tat-ubiquitin-PEP-Alexa 594 to release PEP-Alexa 594, which can be detected by fluorescent microscopy and by the reduction in size in SDS-PAGE [41]. Limitations include low throughput assay format and the need for a secondary detection step such as western blot.

Engineered bacteriophage has been used as cargos of CPPs, in which an Avi-tag was displayed on PIX coat protein of phage. Ypep peptide (YTFGLKTSFNVQ) was displayed on PIII protein to facilitate cell penetration [46]. In vitro biotinylation by BirA generated a biotin tagged phage on PIX protein allowing streptavidin conjugated HRP to bind to phage. The whole complex was introduced to PC-3 human prostate cancer cells for intracellular delivery and the uptake of Ypep-phage-HRP was detected colorimetrically by incubating cells with the substrate $\operatorname{TMB}\left(3,3^{\prime}, 5,5^{\prime}\right.$-tetramethylbenzidine). No significant cell cytotoxicity was observed in the group of Ypep-phage-HRP $\left(5 \times 10^{10} \mathrm{pfu} / \mathrm{mL}\right)$. Subsequently, cells were treated with indole-3-acetic acid (IAA). IAA interacted with HRP to induce cell death only in cells that were first treated with Ypep-phage-HRP. In this approach, phage served as a nanocarriers for exogenous protein delivery with the advantages of easy manipulation and amplification.

Development of functional moieties that allow phenotypic readouts due to CPP cell entry has been a challenging task. First, utilization of a functional group might alter biophysical and chemical properties of CPP-cargo or mask the function of the CPP. Depending on the functional group used, cellular assays need to be optimized and different cell types need to be engineered. Moreover, the efficacy of the assay is shown to be highly dependent on the function and sensitivity of the particular peptide/protein. Functional peptides normally require a $\mu \mathrm{M}-\mathrm{mM}$ concentration for detectable alteration [102], making material generation a challenge.

\subsection{CPPS as Vehicles of Translocation Cassettes Activators}

Gene-based reporter assays have been developed to monitor both cell entry and nuclear translocation. Cre recombinase was fused to Tat peptide and introduced to loxP-STOP-loxP-eGFP expressing cells. In the event of cell penetration and nucleus translocation of Tat-Cre, the STOP DNA segment would be excised, leading to eGFP expression [23]. Yu and colleagues developed a luciferase based transcriptional reporter assay to monitor relative cell permeability of CPPs in 96-well plates. OxDex-activated ester, an agonist of the glucocorticoid receptor (GR) was conjugated to the $\mathrm{N}$ terminus of the CPP (OxDex-CPP). A cell line such as HeLa was co-transfected with two plasmids; one for encoding a fusion protein comprised of Gal4 DNA-binding and dimerization domains (DBD) and a VP16 transactivation domain (Gal4DBD-GRLBD-VP16), and the second plasmid for encoding a Gal4-driven firefly luciferase gene. In the event of OxDex-CPP conjugates entering the intracellular 
domain, OxDex would bind to GRLBD and release the Gal4DBD-GRLBD-VP16 complex from heat shock protein 90 (Hsp90). As a result, fusion protein translocates to nucleus, binds to Gal4 binding site in the firefly luciferase gene and activates it. Subsequently, the expressed luciferase can be quantified [103,104]. Holub and co-workers improved the assay sensitivity by optimizing the affinity of GR variants to the steroid and replacing luciferase by eGFP for detection. As a result, two assays, glucocorticoid-induced eGFP induction (GIGI) and glucocorticoid-induced eGFP translocation (GIGT) were developed. In GIGI assay, eGFP expression is the readout and the amplified assay signal is detected by flow cytometry. In GIGT assay, reporter expression is bypassed such that GR-eGFP fusion protein in the cytosol would translocate to the nucleus upon binding to CPP-GR agonist. This assay requires sophisticated imaging equipment [105].

\subsection{CPPs as Vehicles for Gene Delivery and Expression}

Gene delivery by CPPs has been an attractive alternative to viral gene delivery. In 2003, plasmid DNA encoding luciferase or eGFP gene was linked to the Tat peptide via electrostatic interaction between the negatively charged plasmid and positively charged Tat $[106,107]$. Electrostatic charge interaction was also used to generate a complex between cationic CPPs and anionic siRNAs [108-110]. Readers are referred to an excellent review that summarizes the use of CPPs for nucleic acid delivery [111]. Recently, CPPs have been used as a mean for cell-specific delivery of viral genes [112] and to increase transduction efficiency. Both noncovalent binding (electrostatic interactions) and covalent binding (genetic engineering and chemical conjugation) have been employed to produce CPP-viral particles [113]. Traditional CPPs such as Tat, penetratin, and poly-arginine were the main CPPs used in the discussed studies.

In a separate study, a bacteriophage displaying a CPP was used as a shuttle to deliver an adeno-associated virus (AAV) gene. AAV, cloned within the single-stranded genome of the bacteriophage [114-117], contained a mammalian transgene cassette encoding the cytomegalovirus (CMV) promoter-driven transgene, such as GFP and luciferase, as well as a polyA region that was flanked by inverted terminal repeats (ITRs) from AAV2 genome [116,117]. In the reported studies, Arg-Gly-Asp (RGD-4C) peptide targeting $\alpha \mathrm{v}$ integrin receptors on vascular endothelial cells was displayed at N-terminus of phage PIII protein to facilitate AAV-phage cell entry. The incorporation of the ITRs of the AAV into phage genome has been shown to allow superior transgene expression in mammalian cell $[118,119]$. Depending on the inserted transgene, the phage genome size can be expanded to $13 \mathrm{~Kb}$ or higher, limiting phage amplification and assembly.

\subsection{Utilization of Oocytes to Access CPP Activity}

Natural membranes of specialized cell types can offer valuable information about interaction of CPP and CPP-cargo with the cell membrane. The oocytes of the African frog Xenopus laevis were reported to express low level of ion channels and receptors [120]. The large size of Xenopus oocytes (diameter of up to $1.3 \mathrm{~mm}$ ) allows easy dissection and electrophysiological manipulations [120]. In one study, oocytes were patch clamped under a two-electrode voltage-clamp to monitor changes in transmembrane current upon pore formation by amphipathic CPPs. Application of three amphipathic CPPs, including MPG, $P \beta$, and Pep- 1 , to the voltage-clamped oocytes resulted in increased transmembrane current that resembled channel-formation. Hence, the authors suggested that transmembrane pore formation was likely the mechanism for intracellular entry by the three peptides $[47,48]$.

The large size of oocytes also allows microdissection and injection of various substances. Oocytes can synthesize an exogenous protein when a foreign messenger RNA is injected into their cytoplasm. Examples include neurotransmitter- and voltage-activated ion channels and G-protein coupled receptors [120-122]. Therefore, oocytes could be used as a model for membrane protein expression. Their simplified membrane system also allows the study of peptide-membrane interaction. The simplified version of oocytes includes lipid vesicles, which is the focus of next section. 


\section{Lipid Vesicle-Based In Vitro Assays}

The asymmetric lipid bilayers are patched with cholesterol and transmembrane proteins to provide the dynamic structure and elasticity of the membrane [123,124]. Since the early 1960s, artificial lipid membranes were used to study membrane lipid structure [125]. Today, they are broadly used to study peptide-membrane interaction and lipid reorganization under the conditions lacking endocytosis. General methods were developed to prepare different types of free-standing lipid vesicles [126]. These vesicles can vary in size and lamellar structure and can be synthesized as unilamellar, oligolamellar, and multilamellar vesicles. Lipid classes and their molecule-membrane interactions has been summarized in a 2017 publication by Rosilio. It is worth mentioning that, in most reported studies, mixed lipid models represent a better simulation of the complex biological membranes of cells in normal or diseased state [127]. The plasma membrane of eukaryotic cells are most frequently modeled by mixed bilayers of neutral and charged lipids at different molar fractions. Examples of zwitterionic and anionic lipids are dimyristoylphosphatidylcholine (DMPC) or palmitoyloleoylphosphatidylcholine (POPC) and dimyristoylphosphatidylglycerol (DMPG) or palmitoyloleoylphosphatidylglycerol (POPG), respectively. The molar fraction ratios between zwitterionic and anionic lipids has been varied (1:1, 9.5:0.5, 9:1, 8:2, 7.5:2.5, 3:1 mol/mol) depending on the experimental design. Lipids organize and coexist in solid and fluid phases [128]. DMPC and DMPG are considered as gel phase or ordered lipid, whereas POPC and POPG are referred to fluid phase or dis-ordered lipids [127]. Choice of ordered or disordered lipids may reflect the difference in phospholipid bilayer thickness. For example thickness of DMPC bilayer (carbonyl-to-carbonyl) is about $23 \AA$, whereas the POPC bilayer is $27 \AA$ thick [129].

A considerable number of studies have been conducted with lipid vesicles to gain an insight in the mechanism of membrane binding and penetration of CPPs into intracellular space. It should be noted that key aspects of these studies (lipid components/architecture, CPP to lipid vesicle ratio, $\mathrm{CPP}$ concentration, lipid concentration, buffer composition, temperature, and $\mathrm{pH}$ ) should be matched to physiological conditions to closely reflect biological systems. In addition to lipid composition, peptide to lipid (P/L) ratio can have a significant impact on the outcome of a CPP study. In fact, concentration-enhanced translocation has been reported for multiple CPPs in both cells and synthetic vesicles [130]. The observed increased translocation rates due to increased $\mathrm{P} / \mathrm{L}$ ratio might suggest a translocation mechanism that is facilitated by peptide multimers and/or membrane perturbation, or both. Fuselier and colleagues have reported that translocation of LRLLRWC peptide was significantly reduced when P/L was varied from 1:100 to 1:500, whereas TP2 (PLIYLRLLRGQWC) showed an opposite behavior. This suggested that TP2 translocation might be driven by monomers and could be inhibited by lateral interactions in the membrane [49]. Utilization of lipid bilayers to study CPPs has advantages and limitations. Parameters that define lipid vesicle formation can be well controlled during experimental design, yet cell type specificity is difficult to achieve. CPPs and CPP-cargos might cross the lipid membrane without bilayer disruption. However, the cargo size can be restrictive in the absence of endocytosis.

\subsection{Structural Change in CPPs upon Peptide/Lipid Interaction}

Many tools and techniques have emerged to study peptide/membrane interactions, including differential scanning calorimetry (DSC), plasmon waveguide resonance (PWR), NMR (solution and solid) [33,131,132], X-ray scattering [132,133], isothermal titration calorimetry (ITC), circular dichroism (CD), dual polarization interferometry (DPI) and mass spectrometry (MS) [18]. NMR and X-ray crystallography are capable of providing the residue-specific information. DPI and CD are simpler methods and can be used to measure absorption of optically active chiral molecules. Interaction of penetratin and R8K-biotin (RRMKWKKK(Biotin)-NH2) with a lipid bilayer was monitored by DPI to determine changes in mass per unit area and birefringence (an optical parameter representing bilayer order) with high sensitivity [30]. Both peptides bound strongly to anionic DMPC/DMPG and POPC/POPG, but not to neutral DMPC and POPC bilayers, indicating that electrostatic interaction between a lipid bilayer and CPP was required. $C D$ has been used to monitor structural alterations in 
CPPs induced by the changes in environmental conditions (e.g., $\mathrm{pH}$, temperature). CD spectra reflect the quantity of peptide secondary structure ( $\alpha$-helices, $\beta$-sheets, $\beta$-turns) [134], hence can be used to reveal functional plasticity of CPPs. For example, penetratin assumes a random coil configuration in solution. However, its configuration was altered in the presence of negatively charged vesicles. Interestingly, the extent of this alteration was dependent on the molar fraction of the charged lipids in the vesicles. The spectra were $\alpha$-helical in the presence of low fractions of anionic lipids or low peptide/lipid ratios. On the other hand, it was suggested that penetratin assumes a $\beta$-sheet configuration in the presence of high fractions of anionic lipids or high peptide/lipid ratios. Comparable $\alpha-\beta$ transition was also observed if the composition of lipid vesicles were held constant and the concentration of penetratin was increased [31-34]. CD spectroscopy was also used to examine how different fluorophores influence the interaction of fluorophore-penetratin conjugates with membrane. The N-terminus of penetratin was conjugated to six different fluorophores (CF, TAMRA, RhB, NBD, MCA, and PBA) [135] and conformation of fluorophore-penetratin as well as nature of their interaction with membrane (POPC/POPG, 80:20) was assessed by CD. Interestingly, fluorophore-penetratin conjugates assume different conformations in solution compared to the unconjugated penetratin. Conjugation also increased $\alpha$-helicity of penetratin upon membrane interaction. The two hydrophobic conjugates, RhB- and PBA-penetratin, caused a high membrane disturbance, indicated by calcein release from phospholipid vesicles. It was suggested that the observed increased membrane permeabilization and lipid removal in this study are mainly caused by fluorophore, raising a strong concern for fluorophore conjugation to CPPs. The assays investigating the secondary structure change of CPPs upon interaction with a lipid bilayer can be a valuable complementary approach to decipher mechanism of interaction of CPPs with the cell membrane.

\subsection{CPP Translocation in Dye-Leakage Assay}

Fluorescence techniques in the context of synthetic phospholipid bilayer have been used to analyze peptide interaction, translocation, and membrane perturbation. For this purpose, two strategies are commonly employed: outside-in and inside-out. In the outside-in approach, fluorescence signal induced by the dye labeled CPP is measured inside the vesicles. In the inside-out approach, dye is filled inside the vesicle and its leakage is measured upon CPP entry. Drin and co-workers labeled N-terminus of penetratin with a fluorescent NBD and used CD to monitor its conformation upon interaction with a mixer of POPC/POPG (95:5) small unilamelllar vesicles (SUVs). Although peptide interaction with the lipid bilayer was confirmed, spontaneous translocation of peptides was not observed, suggesting that NBD-penetratin might interact with cell surface components other than the lipids [27]. In a separate study, it was shown that penetratin could slowly translocate into a large unilamellar vesicle (LUV) instead of SUVs, indicating that the translocation of penetratin is depended on the phospholipid composition and requires a membrane potential [35]. A similar finding has shown that the fluorescence labeled octa-arginine derivatives could penetrate into HEK293 cells, but strictly accumulate in the vesicle membrane (POPC/POPG, 90:10) even at $\mu \mathrm{M}$ concentration. These studies have led the authors to suggest that the negative membrane potential is necessary for the CPPs to translocate inside the cell [43].

Enzymes were inserted in the lipid vesicles to improve assay specificity. Chymotrypsin ( $3 \mathrm{uM})$ and terbium (Tb3+) entrapped in LUVs (POPC/POPG, 90:10) were used to investigate entry of CPP linked to an aminomethylcoumarin (AMC) conjugated tripeptide GQF (CPP-GQF-AMC). Upon entering, chymotrypsin cleavage site between Phe-AMC should be cut to release the AMC group, enabling its detection (excitation at $340 \mathrm{~nm}$ and emission at $440 \mathrm{~nm}$ for cleaved AMC) [136]. Addition of dipicolinic acid (DPA) to the vesicle's external environment would result in Tb3+/DPA complex formation if $\mathrm{Tb} 3+$ was leaked due to membrane disruption. Peptides containing an LRLLR motif were screened for spontaneous membrane translocation in the context of synthetic lipid bilayer composed of POPC-LUVs-chymotrypsin $[49,136]$. In addition, a fluorophore-based assay was conducted to measure vesicle permeabilization. POPC-LUVs was prepared with entrapped ANTS, a fluorophore, and its 
quencher DPX, referred to as ANTS/DPX-POPC-LUVs. The vesicles were incubated with CPPs and any membrane leakage could be detected by ANTS fluorescence using a plate reader [49].

Translocation of CPPs that relies on high peptide concentrations possibly involves membrane disruption [137]. The colorimetric assays developed to exhibit color changes upon interactions of peptides and lipid membrane help the visualization of the membrane disruption. Phospholipids and the chromatic lipid-mimetic polymerized polydiacetylene (PDA) were prepared as vesicles. Following the addition of a CPP, the polymer could undergo concentration dependent blue-red transition if any structural perturbation was induced, suggesting peptide-membrane interaction or membrane disruption. Different degrees of color transition constitute an indication for peptides' distinctive mode of interaction with the lipid vesicle interface $[138,139]$.

\subsection{CPPs Translocation and Membrane Potentials}

Eukaryotic cells maintain a net negative potential inside the plasma membrane. Membrane potentials result from the transmembrane lipid asymmetry and can in turn govern the lateral segregation of lipids in the membrane. It was suggested that the modification of membrane potentials could affect CPP translocation [140,141].

In an attempt to create a negative charge inside the lumen, POPC-LUV vesicles were filled with 128 $\mathrm{mM} \mathrm{KCl}$ and $128 \mathrm{mM} \mathrm{NaCl}$ was added to the external environment. A potassium-specific ionophore was embedded in the vesicles to create a negative potential inside the membrane. It was shown that an electrochemical potential could affect translocation of TP2 and its variants crossing the vesicle [49]. The dimension of GUVs resemble a cell and allows study of interaction of CPP with lipids including binding, penetration through the vesicle, and translocation to the GUV lumen $[45,142,143]$. Lin and colleagues reported that the membrane potential served as a driving force for the permeation of cationic CPP, such as 9R and Tat. They applied fluorescently labeled CPPs to GUVs with POPC/POPS (80:20) to monitor membrane crossing by fluorescence correlation spectroscopy (FCS). In addition, the researcher created a tunable membrane potential via the addition of a lipophilic ruthenium (II) complexed with $\mathrm{Ru}(\mathrm{C} 17)_{2}{ }^{2+}$ to induce hyperpolarization in the GUV membrane. The membrane hyperpolarization was driven by a chemical reaction and allowed photo-oxidation of potassium ferricyanide, $\mathrm{Ru}(\mathrm{C} 17)_{2}{ }^{2+}$. $\mathrm{Ru}(\mathrm{C} 17)_{2}{ }^{2+}$ by itself was shown not to alter the membrane permeability. Addition of $\mathrm{Ru}(\mathrm{C} 17)_{2}{ }^{2+}$ to the GUVs enhanced 9 R permeation from $55 \%$ to $78 \%$, possibly due to higher affinity of arginine to the phosphoserine head groups. Lipid vesicles do not bear negative membrane potentials. Therefore, the authors suggested that the membrane potential could be the major cause of discrepancies when CPP permeation is observed in the cellular versus synthetic vesicular [42].

\subsection{CPPs Translocation in Plasma Membrane-Derived Vesicles}

Giant plasma membrane vesicles (GPMVs), also called membrane blebs, are derived from the parental cells' plasma membrane and are used as the model system for native plasma membrane [144]. The lumen of GPMVs contains cytoplasm but is free of cellular organelles and cytoskeleton, therefore it lacks energy fuels [145]. Readers are referred to a deep dive in GPMVs written by the Leventals [146]. The lipids of GPMVs were composed of phospholipid/cholesterol at a ratio of approximately 2:1 and retained the sophisticated complexity of the plasma membrane [147]. Saalik and colleagues generated GPMVs from RBL-2H3 and HeLa cells to study six known fluorescent labeled CPPs including Tat, penetratin, 9R, MAP, transportan, and TP10 in the absence of endocytotic processes [36]. Dye-CPPs were incubated with GMPVs and their penetration was quantified by flow cytometry and confocal microscopy. The authors showed that all tested CPPs accumulated into the lumen of GPMVs at $25^{\circ} \mathrm{C}$ and lower temperatures. It should be noted that the preservation of membrane surface properties is the key step in GPMVs preparation [146]. Liu and co-workers pointed out that the chemical vesiculants (e.g., formaldehyde and dithiothreitol) and osmotic buffers that are required for vesicle formation could disrupt membrane structure. They herein developed a high yield nanomaterial-assisted strategy that used light irradiation to generate GPMVs in biocompatible medium such as Dulbecco's Modified 
Eagle's Medium [148]. Further optimization of GPMVs has expanded their application as an intact membrane with lipid and protein complexity of mammalian plasma membrane. Artificial plasma membranes are also used to study protein function. For example, sophisticated design of ion channels were incorporated in lipid vesicles to develop sensing applications [149]. Moreover, computational methods such as simulation of interaction of CPPs with artificial lipid bilayers have been utilized. Molecular dynamics simulations can provide means to gain insight into the peptide/membrane interactions and various energy-independent mechanisms. A more extensive review of the molecular dynamics application for CPPs can be found in review written by Reid [150].

\section{Concluding Remarks}

Tremendous effort has been made for the discovery and characterization of novel CPPs for efficient and specific cytoplasmic delivery. Fundamental understanding of the mechanism of cell entry, endosomal escape, and interaction of CPPs with the cell membrane are critical for their advancement in the clinic. Biological relevance of the cell lines used in the in vitro assays should be taken into consideration to preserve in vitro-in vivo connectivity. In this review, we have summarized current strategies that were utilized or could be employed in evaluating CPP-cargos. Since each technique bears its limitations, exploiting orthogonal strategies is recommended to identify the most efficient CPPs as vehicles for therapeutic cargo delivery.

Author Contributions: Original draft preparation, review and editing, J.L., S.A.; All authors have read and agreed to the published version of the manuscript.

Funding: This research received no external funding.

Acknowledgments: This research was funded by Eli Lilly \& Company. The funder provided support in the form of salaries for authors and had no additional role in the manuscript preparation.

Conflicts of Interest: At the time of this manuscript preparation, all authors were employees of Eli Lilly and Company. The authors declare no conflict of interest.

\section{Abbreviations}

$\begin{array}{ll}\text { CPP } & \text { cell-penetrating peptide } \\ \text { GFP } & \text { green fluorescence protein } \\ \text { eGFP } & \text { enhanced green fluorescence protein } \\ \text { YFP } & \text { yellow fluorescence protein } \\ \text { eYFP } & \text { enhanced yellow fluorescence protein } \\ \text { RFP } & \text { red fluorescence protein } \\ \text { DMPC } & \text { dimyristoylphosphatidylcholine } \\ \text { DMPG } & \text { dimyristoylphosphatidylglycerol } \\ \text { DOPC } & \text { dioleoylphosphatidylcholine } \\ \text { POPC } & \text { palmitoyloleoylphosphatidylcholine } \\ \text { POPG } & \text { palmitoyloleoylphosphatidylglycerol } \\ \text { POPS } & \text { palmitoyloleoylphosphatidylserine } \\ \text { SUV } & \text { small unilamelllar vesicle } \\ \text { LUV } & \text { large unilamellar vesicle } \\ \text { GUV } & \text { giant unilamellar vesicle } \\ \text { GPMV } & \text { giant plasma membrane vesicle } \\ \text { MLV } & \text { multilamellar vesicle } \\ \text { CD } & \text { circular dichroism } \\ \text { DPI } & \text { dual polarization interferometry } \\ \text { NBD } & \text { N-(7-nitro-2,1,3-benzoxadiazol-4-yl)glycine } \\ \text { TAMRA } & \text { 5(6)-carboxytetramethylrhodamine } \\ \text { CF } & 5(6) \text {-carboxyfluorescein } \\ \text { RhB } & \text { N-(9-(2-carboxyphenyl)-6-(diethylamino)-3Hxanthen-3-ylidene)-N-ethylethanaminium } \\ \text { MCA } & \text { (7-methoxycoumarin-4-yl)acetic } \\ \text { PBA } & \text { 1-pyrenebutyric acid } \\ \end{array}$




\section{References}

1. Williamson, P.; Schlegel, R.A. Back and forth: The regulation and function of transbilayer phospholipid movement in eukaryotic cells. Mol. Membr. Biol. 1994, 11, 199-216. [CrossRef] [PubMed]

2. Manno, S.; Takakuwa, Y.; Mohandas, N. Identification of a functional role for lipid asymmetry in biological membranes: Phosphatidylserine-skeletal protein interactions modulate membrane stability. Proc. Natl. Acad. Sci. USA 2002, 99, 1943-1948. [CrossRef] [PubMed]

3. Overington, J.P.; Al-Lazikani, B.; Hopkins, A.L. How many drug targets are there? Nat. Rev. Drug Discov. 2006, 5, 993-996. [CrossRef]

4. Peraro, L.; Kritzer, J.A. Emerging methods and design principles for cell-penetrant peptides. Angew. Chem. Int. Ed. Engl. 2018, 57, 11868-11881. [CrossRef] [PubMed]

5. Tashima, T. Intelligent substance delivery into cells using cell-penetrating peptides. Bioorg. Med. Chem. Lett. 2017, 27, 121-130. [CrossRef]

6. Vives, E.; Brodin, P.; Lebleu, B. A truncated HIV-1 Tat protein basic domain rapidly translocates through the plasma membrane and accumulates in the cell nucleus. J. Biol. Chem. 1997, 272, 16010-16017. [CrossRef]

7. Park, J.; Ryu, J.; Kim, K.A.; Lee, H.J.; Bahn, J.H.; Han, K.; Choi, E.Y.; Lee, K.S.; Kwon, H.Y.; Choi, S.Y. Mutational analysis of a human immunodeficiency virus type 1 Tat protein transduction domain which is required for delivery of an exogenous protein into mammalian cells. J. Gen. Virol. 2002, 83, 1173-1181. [CrossRef]

8. Tripathi, P.P.; Arami, H.; Banga, I.; Gupta, J.; Gandhi, S. Cell penetrating peptides in preclinical and clinical cancer diagnosis and therapy. Oncotarget 2018, 9, 37252-37267. [CrossRef]

9. Guidotti, G.; Brambilla, L.; Rossi, D. Cell-penetrating peptides: From basic research to clinics. Trends Pharmacol. Sci. 2017, 38, 406-424. [CrossRef]

10. Derossi, D.; Joliot, A.H.; Chassaing, G.; Prochiantz, A. The third helix of the Antennapedia homeodomain translocates through biological membranes. J. Biol. Chem. 1994, 269, 10444-10450.

11. Joliot, A.; Pernelle, C.; Deagostini-Bazin, H.; Prochiantz, A. Antennapedia homeobox peptide regulates neural morphogenesis. Proc. Natl. Acad. Sci. USA 1991, 88, 1864-1868. [CrossRef] [PubMed]

12. Gallo, M.; Defaus, S.; Andreu, D. 1988-2018: Thirty years of drug smuggling at the nano scale. Challenges and opportunities of cell-penetrating peptides in biomedical research. Arch. Biochem. Biophys. 2019, 661, 74-86. [CrossRef] [PubMed]

13. Stewart, M.P.; Lorenz, A.; Dahlman, J.; Sahay, G. Challenges in carrier-mediated intracellular delivery: Moving beyond endosomal barriers. Wiley Interdiscip Rev. Nanomed. Nanobiotechnol. 2016, 8, 465-478. [CrossRef]

14. Dinca, A.; Chien, W.M.; Chin, M.T. Intracellular delivery of proteins with cell-penetrating peptides for therapeutic uses in human disease. Int. J. Mol. Sci. 2016, 17, 263. [CrossRef] [PubMed]

15. Trabulo, S.; Cardoso, A.L.; Mano, M.; De Lima, M.C. Cell-penetrating peptides-mechanisms of cellular uptake and generation of delivery systems. Pharmaceuticals 2010, 3, 961-993. [CrossRef]

16. Duchardt, F.; Fotin-Mleczek, M.; Schwarz, H.; Fischer, R.; Brock, R. A comprehensive model for the cellular uptake of cationic cell-penetrating peptides. Traffic 2007, 8, 848-866. [CrossRef]

17. Kauffman, W.B.; Fuselier, T.; He, J.; Wimley, W.C. Mechanism matters: A taxonomy of cell penetrating peptides. Trends Biochem. Sci. 2015, 40, 749-764. [CrossRef]

18. Alves, I.D.; Jiao, C.Y.; Aubry, S.; Aussedat, B.; Burlina, F.; Chassaing, G.; Sagan, S. Cell biology meets biophysics to unveil the different mechanisms of penetratin internalization in cells. Biochim. Biophys. Acta 2010, 1798, 2231-2239. [CrossRef]

19. Tunnemann, G.; Martin, R.M.; Haupt, S.; Patsch, C.; Edenhofer, F.; Cardoso, M.C. Cargo-dependent mode of uptake and bioavailability of TAT-containing proteins and peptides in living cells. FASEB J. 2006, 20, 1775-1784. [CrossRef]

20. Habault, J.; Poyet, J.L. Recent advances in cell penetrating peptide-based anticancer therapies. Molecules 2019, 24, 927. [CrossRef]

21. Erazo-Oliveras, A.; Muthukrishnan, N.; Baker, R.; Wang, T.Y.; Pellois, J.P. Improving the endosomal escape of cell-penetrating peptides and their cargos: Strategies and challenges. Pharmaceuticals 2012, 5, 1177-1209. [CrossRef] [PubMed]

22. Kaplan, I.M.; Wadia, J.S.; Dowdy, S.F. Cationic TAT peptide transduction domain enters cells by macropinocytosis. J. Control. Release 2005, 102, 247-253. [CrossRef] [PubMed] 
23. Wadia, J.S.; Stan, R.V.; Dowdy, S.F. Transducible TAT-HA fusogenic peptide enhances escape of TAT-fusion proteins after lipid raft macropinocytosis. Nat. Med. 2004, 10, 310-315. [CrossRef] [PubMed]

24. El-Andaloussi, S.; Johansson, H.J.; Lundberg, P.; Langel, U. Induction of splice correction by cell-penetrating peptide nucleic acids. J. Gene Med. 2006, 8, 1262-1273. [CrossRef] [PubMed]

25. Thoren, P.E.; Persson, D.; Isakson, P.; Goksor, M.; Onfelt, A.; Norden, B. Uptake of analogs of penetratin, Tat(48-60) and oligoarginine in live cells. Biochem. Biophys. Res. Commun. 2003, 307, 100-107. [CrossRef]

26. Rydberg, H.A.; Matson, M.; Amand, H.L.; Esbjorner, E.K.; Norden, B. Effects of tryptophan content and backbone spacing on the uptake efficiency of cell-penetrating peptides. Biochemistry 2012, 51, 5531-5539. [CrossRef]

27. Drin, G.; Mazel, M.; Clair, P.; Mathieu, D.; Kaczorek, M.; Temsamani, J. Physico-chemical requirements for cellular uptake of pAntp peptide. Role of lipid-binding affinity. Eur. J. Biochem. 2001, 268, 1304-1314. [CrossRef]

28. Hallbrink, M.; Floren, A.; Elmquist, A.; Pooga, M.; Bartfai, T.; Langel, U. Cargo delivery kinetics of cell-penetrating peptides. Biochim. Biophys. Acta 2001, 1515, 101-109. [CrossRef]

29. Peraro, L.; Deprey, K.L.; Moser, M.K.; Zou, Z.; Ball, H.L.; Levine, B.; Kritzer, J.A. Cell penetration profiling using the chloroalkane penetration assay. J. Am. Chem. Soc. 2018, 140, 11360-11369. [CrossRef]

30. Hirst, D.J.; Lee, T.H.; Kulkarni, K.; Wilce, J.A.; Aguilar, M.I. The impact of cell-penetrating peptides on membrane bilayer structure during binding and insertion. Biochim. Biophys. Acta 2016, 1858, 1841-1849. [CrossRef]

31. Magzoub, M.; Eriksson, L.E.; Graslund, A. Conformational states of the cell-penetrating peptide penetratin when interacting with phospholipid vesicles: Effects of surface charge and peptide concentration. Biochim. Biophys. Acta 2002, 1563, 53-63. [CrossRef]

32. Magzoub, M.; Eriksson, L.E.; Graslund, A. Comparison of the interaction, positioning, structure induction and membrane perturbation of cell-penetrating peptides and non-translocating variants with phospholipid vesicles. Biophys. Chem. 2003, 103, 271-288. [CrossRef]

33. Lindberg, M.; Biverstahl, H.; Graslund, A.; Maler, L. Structure and positioning comparison of two variants of penetratin in two different membrane mimicking systems by NMR. Eur. J. Biochem. 2003, 270, 3055-3063. [CrossRef] [PubMed]

34. Lee, C.C.; Sun, Y.; Huang, H.W. Membrane-mediated peptide conformation change from alpha-monomers to beta-aggregates. Biophys. J. 2010, 98, 2236-2245. [CrossRef]

35. Terrone, D.; Sang, S.L.; Roudaia, L.; Silvius, J.R. Penetratin and related cell-penetrating cationic peptides can translocate across lipid bilayers in the presence of a transbilayer potential. Biochemistry 2003, 42, 13787-13799. [CrossRef]

36. Saalik, P.; Niinep, A.; Pae, J.; Hansen, M.; Lubenets, D.; Langel, U.; Pooga, M. Penetration without cells: Membrane translocation of cell-penetrating peptides in the model giant plasma membrane vesicles. J. Control. Release 2011, 153, 117-125. [CrossRef]

37. Chen, Y.N.; Sharma, S.K.; Ramsey, T.M.; Jiang, L.; Martin, M.S.; Baker, K.; Adams, P.D.; Bair, K.W.; Kaelin, W.G., Jr. Selective killing of transformed cells by cyclin/cyclin-dependent kinase 2 antagonists. Proc. Natl. Acad. Sci. USA 1999, 96, 4325-4329. [CrossRef]

38. Caignard, G.; Bourai, M.; Jacob, Y.; Infection-MAPping project I-MAP; Tangy, F.; Vidalain, P.O. Inhibition of IFN-alpha/beta signaling by two discrete peptides within measles virus $\mathrm{V}$ protein that specifically bind STAT1 and STAT2. Virology 2009, 383, 112-120. [CrossRef]

39. Bonny, C.; Oberson, A.; Negri, S.; Sauser, C.; Schorderet, D.F. Cell-permeable peptide inhibitors of JNK: Novel blockers of beta-cell death. Diabetes 2001, 50,77-82. [CrossRef]

40. Wang, J.; Van De Water, T.R.; Bonny, C.; de Ribaupierre, F.; Puel, J.L.; Zine, A. A peptide inhibitor of c-Jun $\mathrm{N}$-terminal kinase protects against both aminoglycoside and acoustic trauma-induced auditory hair cell death and hearing loss. J. Neurosci. 2003, 23, 8596-8607. [CrossRef]

41. Loison, F.; Nizard, P.; Sourisseau, T.; Le Goff, P.; Debure, L.; Le Drean, Y.; Michel, D. A ubiquitin-based assay for the cytosolic uptake of protein transduction domains. Mol. Ther. 2005, 11, 205-214. [CrossRef]

42. Lin, C.C.; Bachmann, M.; Bachler, S.; Venkatesan, K.; Dittrich, P.S. Tunable membrane potential reconstituted in giant vesicles promotes permeation of cationic peptides at nanomolar concentrations. ACS Appl. Mater. Interfaces 2018, 10, 41909-41916. [CrossRef] [PubMed] 
43. Purkayastha, N.; Eyer, K.; Robinson, T.; Dittrich, P.S.; Beck, A.K.; Seebach, D.; Kolesinska, B.; Cadalbert, R. Enantiomeric and diastereoisomeric (mixed) L/D-octaarginine derivatives-A simple way of modulating the properties of cell-penetrating peptides. Chem. Biodivers. 2013, 10, 1165-1184. [CrossRef]

44. Kim, D.; Lee, I.H.; Kim, S.; Choi, M.; Kim, H.; Ahn, S.; Saw, P.E.; Jeon, H.; Lee, Y.; Jon, S. A specific STAT3-binding peptide exerts antiproliferative effects and antitumor activity by inhibiting STAT3 phosphorylation and signaling. Cancer Res. 2014, 74, 2144-2151. [CrossRef] [PubMed]

45. Moghal, M.M.R.; Hossain, F.; Yamazaki, M. Action of antimicrobial peptides and cell-penetrating peptides on membrane potential revealed by the single GUV method. Biophys. Rev. 2020, 12, 339-348. [CrossRef] [PubMed]

46. DePorter, S.M.; McNaughton, B.R. Engineered M13 bacteriophage nanocarriers for intracellular delivery of exogenous proteins to human prostate cancer cells. Bioconjug. Chem. 2014, 25, 1620-1625. [CrossRef]

47. Deshayes, S.; Gerbal-Chaloin, S.; Morris, M.C.; Aldrian-Herrada, G.; Charnet, P.; Divita, G.; Heitz, F. On the mechanism of non-endosomial peptide-mediated cellular delivery of nucleic acids. Biochim. Biophys. Acta 2004, 1667, 141-147. [CrossRef]

48. Deshayes, S.; Plenat, T.; Charnet, P.; Divita, G.; Molle, G.; Heitz, F. Formation of transmembrane ionic channels of primary amphipathic cell-penetrating peptides. Consequences on the mechanism of cell penetration. Biochim. Biophys. Acta 2006, 1758, 1846-1851. [CrossRef]

49. Fuselier, T.; Wimley, W.C. Spontaneous membrane translocating peptides: The role of leucine-arginine consensus motifs. Biophys. J. 2017, 113, 835-846. [CrossRef] [PubMed]

50. Jiao, C.Y.; Delaroche, D.; Burlina, F.; Alves, I.D.; Chassaing, G.; Sagan, S. Translocation and endocytosis for cell-penetrating peptide internalization. J. Biol. Chem. 2009, 284, 33957-33965. [CrossRef]

51. Bird, G.H.; Mazzola, E.; Opoku-Nsiah, K.; Lammert, M.A.; Godes, M.; Neuberg, D.S.; Walensky, L.D. Biophysical determinants for cellular uptake of hydrocarbon-stapled peptide helices. Nat. Chem. Biol. 2016, 12, 845-852. [CrossRef] [PubMed]

52. Ochocki, J.D.; Mullen, D.G.; Wattenberg, E.V.; Distefano, M.D. Evaluation of a cell penetrating prenylated peptide lacking an intrinsic fluorophore via in situ click reaction. Bioorg. Med. Chem. Lett. 2011, 21, 4998-5001. [CrossRef] [PubMed]

53. Lindgren, M.; Gallet, X.; Soomets, U.; Hallbrink, M.; Brakenhielm, E.; Pooga, M.; Brasseur, R.; Langel, U. Translocation properties of novel cell penetrating transportan and penetratin analogues. Bioconjug. Chem. 2000, 11, 619-626. [CrossRef] [PubMed]

54. Jaye, D.L.; Geigerman, C.M.; Fuller, R.E.; Akyildiz, A.; Parkos, C.A. Direct fluorochrome labeling of phage display library clones for studying binding specificities: Applications in flow cytometry and fluorescence microscopy. J. Immunol. Methods 2004, 295, 119-127. [CrossRef]

55. Kelly, K.A.; Waterman, P.; Weissleder, R. In vivo imaging of molecularly targeted phage. Neoplasia 2006, 8 , 1011-1018. [CrossRef]

56. Banerjee, D.; Liu, A.P.; Voss, N.R.; Schmid, S.L.; Finn, M.G. Multivalent display and receptor-mediated endocytosis of transferrin on virus-like particles. Chembiochem 2010, 11, 1273-1279. [CrossRef]

57. Hess, G.T.; Guimaraes, C.P.; Spooner, E.; Ploegh, H.L.; Belcher, A.M. Orthogonal labeling of M13 minor capsid proteins with DNA to self-assemble end-to-end multiphage structures. ACS Synth. Biol. 2013, 2, 490-496. [CrossRef]

58. McIntyre, J.C.; Sleight, R.G. Fluorescence assay for phospholipid membrane asymmetry. Biochemistry 1991, 30, 11819-11827. [CrossRef]

59. Ogawa, M.; Kosaka, N.; Longmire, M.R.; Urano, Y.; Choyke, P.L.; Kobayashi, H. Fluorophore-quencher based activatable targeted optical probes for detecting in vivo cancer metastases. Mol. Pharm. 2009, 6, 386-395. [CrossRef]

60. He, J.; Kauffman, W.B.; Fuselier, T.; Naveen, S.K.; Voss, T.G.; Hristova, K.; Wimley, W.C. Direct cytosolic delivery of polar cargo to cells by spontaneous membrane-translocating peptides. J. Biol. Chem. 2013, 288, 29974-29986. [CrossRef]

61. Lundberg, M.; Johansson, M. Is VP22 nuclear homing an artifact? Nat. Biotechnol. 2001, 19, 713-714. [CrossRef] [PubMed]

62. Maulucci, G.; Chiarpotto, M.; Papi, M.; Samengo, D.; Pani, G.; De Spirito, M. Quantitative analysis of autophagic flux by confocal pH-imaging of autophagic intermediates. Autophagy 2015, 11, 1905-1916. [CrossRef] 
63. Shen, Y.; Rosendale, M.; Campbell, R.E.; Perrais, D. pHuji, a pH-sensitive red fluorescent protein for imaging of exo- and endocytosis. J. Cell. Biol. 2014, 207, 419-432. [CrossRef] [PubMed]

64. Burgstaller, S.; Bischof, H.; Gensch, T.; Stryeck, S.; Gottschalk, B.; Ramadani-Muja, J.; Eroglu, E.; Rost, R.; Balfanz, S.; Baumann, A.; et al. pH-Lemon, a fluorescent protein-based $\mathrm{pH}$ reporter for acidic compartments. ACS Sens. 2019, 4, 883-891. [CrossRef] [PubMed]

65. Shekhawat, S.S.; Ghosh, I. Split-protein systems: Beyond binary protein-protein interactions. Curr. Opin. Chem. Biol. 2011, 15, 789-797. [CrossRef] [PubMed]

66. Kudla, J.; Bock, R. Lighting the way to protein-protein interactions: Recommendations on best practices for bimolecular fluorescence complementation analyses. Plant Cell 2016, 28, 1002-1008. [CrossRef]

67. Cabantous, S.; Terwilliger, T.C.; Waldo, G.S. Protein tagging and detection with engineered self-assembling fragments of green fluorescent protein. Nat. Biotechnol. 2005, 23, 102-107. [CrossRef]

68. Lindman, S.; Hernandez-Garcia, A.; Szczepankiewicz, O.; Frohm, B.; Linse, S. In vivo protein stabilization based on fragment complementation and a split GFP system. Proc. Natl. Acad. Sci. USA 2010, 107, 19826-19831. [CrossRef]

69. Cabantous, S.; Waldo, G.S. In vivo and in vitro protein solubility assays using split GFP. Nat. Methods 2006, 3, 845-854. [CrossRef]

70. Kim, J.S.; Choi, D.K.; Park, S.W.; Shin, S.M.; Bae, J.; Kim, D.M.; Yoo, T.H.; Kim, Y.S. Quantitative assessment of cellular uptake and cytosolic access of antibody in living cells by an enhanced split GFP complementation assay. Biochem. Biophys. Res. Commun. 2015, 467, 771-777. [CrossRef]

71. Hu, C.D.; Chinenov, Y.; Kerppola, T.K. Visualization of interactions among bZIP and Rel family proteins in living cells using bimolecular fluorescence complementation. Mol. Cell 2002, 9, 789-798. [CrossRef]

72. Walter, M.; Chaban, C.; Schutze, K.; Batistic, O.; Weckermann, K.; Nake, C.; Blazevic, D.; Grefen, C.; Schumacher, K.; Oecking, C.; et al. Visualization of protein interactions in living plant cells using bimolecular fluorescence complementation. Plant J. 2004, 40, 428-438. [CrossRef] [PubMed]

73. Hu, C.D.; Kerppola, T.K. Simultaneous visualization of multiple protein interactions in living cells using multicolor fluorescence complementation analysis. Nat. Biotechnol. 2003, 21, 539-545. [CrossRef]

74. Waadt, R.; Schmidt, L.K.; Lohse, M.; Hashimoto, K.; Bock, R.; Kudla, J. Multicolor bimolecular fluorescence complementation reveals simultaneous formation of alternative CBL/CIPK complexes in planta. Plant J. 2008, 56, 505-516. [CrossRef] [PubMed]

75. Ohashi, K.; Kiuchi, T.; Shoji, K.; Sampei, K.; Mizuno, K. Visualization of cofilin-actin and Ras-Raf interactions by bimolecular fluorescence complementation assays using a new pair of split Venus fragments. Biotechniques 2012, 52, 45-50. [CrossRef]

76. Gookin, T.E.; Assmann, S.M. Significant reduction of BiFC non-specific assembly facilitates in planta assessment of heterotrimeric G-protein interactors. Plant J. 2014, 80, 553-567. [CrossRef] [PubMed]

77. Milech, N.; Longville, B.A.; Cunningham, P.T.; Scobie, M.N.; Bogdawa, H.M.; Winslow, S.; Anastasas, M.; Connor, T.; Ong, F.; Stone, S.R.; et al. GFP-complementation assay to detect functional CPP and protein delivery into living cells. Sci. Rep. 2015, 5, 18329. [CrossRef]

78. Zhang, P.; Monteiro da Silva, G.; Deatherage, C.; Burd, C.; DiMaio, D. Cell-penetrating peptide mediates intracellular membrane passage of human papillomavirus L2 protein to trigger retrograde trafficking. Cell 2018, 174, 1465-1476. [CrossRef]

79. Lonn, P.; Kacsinta, A.D.; Cui, X.S.; Hamil, A.S.; Kaulich, M.; Gogoi, K.; Dowdy, S.F. Enhancing endosomal escape for intracellular delivery of macromolecular biologic therapeutics. Sci. Rep. 2016, 6, 32301. [CrossRef]

80. Keppler, A.; Gendreizig, S.; Gronemeyer, T.; Pick, H.; Vogel, H.; Johnsson, K. A general method for the covalent labeling of fusion proteins with small molecules in vivo. Nat. Biotechnol. 2003, 21, 86-89. [CrossRef]

81. Gautier, A.; Juillerat, A.; Heinis, C.; Correa, I.R., Jr.; Kindermann, M.; Beaufils, F.; Johnsson, K. An engineered protein tag for multiprotein labeling in living cells. Chem. Biol. 2008, 15, 128-136. [CrossRef]

82. George, N.; Pick, H.; Vogel, H.; Johnsson, N.; Johnsson, K. Specific labeling of cell surface proteins with chemically diverse compounds. J. Am. Chem Soc. 2004, 126, 8896-8897. [CrossRef] [PubMed]

83. Yin, J.; Straight, P.D.; McLoughlin, S.M.; Zhou, Z.; Lin, A.J.; Golan, D.E.; Kelleher, N.L.; Kolter, R.; Walsh, C.T. Genetically encoded short peptide tag for versatile protein labeling by Sfp phosphopantetheinyl transferase. Proc. Natl. Acad. Sci. USA 2005, 102, 15815-15820. [CrossRef] [PubMed]

84. Shi, X.; Jung, Y.; Lin, L.J.; Liu, C.; Wu, C.; Cann, I.K.; Ha, T. Quantitative fluorescence labeling of aldehyde-tagged proteins for single-molecule imaging. Nat. Methods 2012, 9, 499-503. [CrossRef] [PubMed] 
85. Verdurmen, W.P.; Luginbuhl, M.; Honegger, A.; Pluckthun, A. Efficient cell-specific uptake of binding proteins into the cytoplasm through engineered modular transport systems. J. Control. Release 2015, 200, 13-22. [CrossRef] [PubMed]

86. Verdurmen, W.P.R.; Mazlami, M.; Pluckthun, A. A quantitative comparison of cytosolic delivery via different protein uptake systems. Sci. Rep. 2017, 7, 13194. [CrossRef] [PubMed]

87. Verdurmen, W.P.R.; Mazlami, M.; Pluckthun, A. A biotin ligase-based assay for the quantification of the cytosolic delivery of therapeutic proteins. Methods Mol. Biol. 2017, 1575, 223-236.

88. Smelyanski, L.; Gershoni, J.M. Site directed biotinylation of filamentous phage structural proteins. Virol. J. 2011, 8, 495. [CrossRef]

89. Beckett, D.; Kovaleva, E.; Schatz, P.J. A minimal peptide substrate in biotin holoenzyme synthetase-catalyzed biotinylation. Protein Sci. 1999, 8, 921-929. [CrossRef]

90. Hoffmann, K.; Milech, N.; Juraja, S.M.; Cunningham, P.T.; Stone, S.R.; Francis, R.W.; Anastasas, M.; Hall, C.M.; Heinrich, T.; Bogdawa, H.M.; et al. A platform for discovery of functional cell-penetrating peptides for efficient multi-cargo intracellular delivery. Sci. Rep. 2018, 8, 12538. [CrossRef]

91. Peraro, L.; Zou, Z.; Makwana, K.M.; Cummings, A.E.; Ball, H.L.; Yu, H.; Lin, Y.S.; Levine, B.; Kritzer, J.A. Diversity-oriented stapling yields intrinsically cell-penetrant inducers of autophagy. J. Am. Chem. Soc. 2017, 139, 7792-7802. [CrossRef] [PubMed]

92. Urh, M.; Rosenberg, M. HaloTag, a platform technology for protein analysis. Curr. Chem. Genomics 2012, 6, $72-78$. [CrossRef]

93. Encell, L.P.; Friedman Ohana, R.; Zimmerman, K.; Otto, P.; Vidugiris, G.; Wood, M.G.; Los, G.V.; McDougall, M.G.; Zimprich, C.; Karassina, N.; et al. Development of a dehalogenase-based protein fusion tag capable of rapid, selective and covalent attachment to customizable ligands. Curr. Chem. Genomics 2012, 6, 55-71. [CrossRef] [PubMed]

94. Gronemeyer, T.; Godin, G.; Johnsson, K. Adding value to fusion proteins through covalent labelling. Curr. Opin. Biotechnol. 2005, 16, 453-458. [CrossRef] [PubMed]

95. Peier, A.; Ge, L.; Boyer, N.; Biswas, K.; Huang, C.; Garrigou, M.; Tellers, D.; Ha, S.; Lane, S.D.; Brown, C.; et al. NanoClick Assay: A high throughput, target-agnostic permeability assay that combines NanoBRET technology with intracellular click chemistry. Proceeding of the American Peptide Society (APS), Monterey, CA, USA, 22 June 2019.

96. Lindsay, M.A. Peptide-mediated cell delivery: Application in protein target validation. Curr. Opin. Pharmacol. 2002, 2, 587-594. [CrossRef]

97. Fawell, S.; Seery, J.; Daikh, Y.; Moore, C.; Chen, L.L.; Pepinsky, B.; Barsoum, J. Tat-mediated delivery of heterologous proteins into cells. Proc. Natl. Acad. Sci. USA 1994, 91, 664-668. [CrossRef]

98. Standley, S.M.; Toft, D.J.; Cheng, H.; Soukasene, S.; Chen, J.; Raja, S.M.; Band, V.; Band, H.; Cryns, V.L.; Stupp, S.I. Induction of cancer cell death by self-assembling nanostructures incorporating a cytotoxic peptide. Cancer Res. 2010, 70, 3020-3026. [CrossRef]

99. Ellerby, H.M.; Arap, W.; Ellerby, L.M.; Kain, R.; Andrusiak, R.; Rio, G.D.; Krajewski, S.; Lombardo, C.R.; Rao, R.; Ruoslahti, E.; et al. Anti-cancer activity of targeted pro-apoptotic peptides. Nat. Med. 1999, 5, 1032-1038. [CrossRef]

100. Coleman, D.R.T.; Ren, Z.; Mandal, P.K.; Cameron, A.G.; Dyer, G.A.; Muranjan, S.; Campbell, M.; Chen, X.; McMurray, J.S. Investigation of the binding determinants of phosphopeptides targeted to the SRC homology 2 domain of the signal transducer and activator of transcription 3. Development of a high-affinity peptide inhibitor. J. Med. Chem. 2005, 48, 6661-6670. [CrossRef]

101. Turkson, J.; Ryan, D.; Kim, J.S.; Zhang, Y.; Chen, Z.; Haura, E.; Laudano, A.; Sebti, S.; Hamilton, A.D.; Jove, R. Phosphotyrosyl peptides block Stat3-mediated DNA binding activity, gene regulation, and cell transformation. J. Biol. Chem. 2001, 276, 45443-45455. [CrossRef]

102. Saw, P.E.; Song, E.W. Phage display screening of therapeutic peptide for cancer targeting and therapy. Protein Cell 2019, 10, 787-807. [CrossRef] [PubMed]

103. Tan, N.C.; Yu, P.; Kwon, Y.U.; Kodadek, T. High-throughput evaluation of relative cell permeability between peptoids and peptides. Bioorg. Med. Chem. 2008, 16, 5853-5861. [CrossRef]

104. Yu, P.; Liu, B.; Kodadek, T. A high-throughput assay for assessing the cell permeability of combinatorial libraries. Nat. Biotechnol. 2005, 23, 746-751. [CrossRef] [PubMed] 
105. Holub, J.M.; Larochelle, J.R.; Appelbaum, J.S.; Schepartz, A. Improved assays for determining the cytosolic access of peptides, proteins, and their mimetics. Biochemistry 2013, 52, 9036-9046. [CrossRef] [PubMed]

106. Ignatovich, I.A.; Dizhe, E.B.; Pavlotskaya, A.V.; Akifiev, B.N.; Burov, S.V.; Orlov, S.V.; Perevozchikov, A.P. Complexes of plasmid DNA with basic domain 47-57 of the HIV-1 Tat protein are transferred to mammalian cells by endocytosis-mediated pathways. J. Biol. Chem. 2003, 278, 42625-42636. [CrossRef] [PubMed]

107. Rudolph, C.; Plank, C.; Lausier, J.; Schillinger, U.; Muller, R.H.; Rosenecker, J. Oligomers of the arginine-rich motif of the HIV-1 TAT protein are capable of transferring plasmid DNA into cells. J. Biol. Chem. 2003, 278, 11411-11418. [CrossRef]

108. Freire, J.M.; Rego de Figueiredo, I.; Valle, J.; Veiga, A.S.; Andreu, D.; Enguita, F.J.; Castanho, M.A. siRNA-cell-penetrating peptides complexes as a combinatorial therapy against chronic myeloid leukemia using BV173 cell line as model. J. Control. Release 2017, 245, 127-136. [CrossRef]

109. Suh, J.S.; Lee, H.J.; Nam, H.; Jo, B.S.; Lee, D.W.; Kim, J.H.; Lee, J.Y.; Chung, C.P.; Lee, G.; Park, Y.J. Control of cancer stem cell like population by intracellular target identification followed by the treatment with peptide-siRNA complex. Biochem. Biophys. Res. Commun. 2017, 491, 827-833. [CrossRef]

110. Tuttolomondo, M.; Casella, C.; Hansen, P.L.; Polo, E.; Herda, L.M.; Dawson, K.A.; Ditzel, H.J.; Mollenhauer, J. Human DMBT1-derived cell-penetrating peptides for intracellular siRNA delivery. Mol. Ther. Nucleic Acids 2017, 8, 264-276. [CrossRef]

111. Taylor, R.E.; Zahid, M. Cell penetrating peptides, novel vectors for gene therapy. Pharmaceutics 2020, $12,225$. [CrossRef]

112. Lundstrom, K. Viral vectors in gene Therapy. Diseases 2018, 6, 42. [CrossRef] [PubMed]

113. Vanova, J.; Hejtmankova, A.; Kalbacova, M.H.; Spanielova, H. The utilization of cell-penetrating peptides in the intracellular delivery of viral nanoparticles. Materials 2019, 12, 2671. [CrossRef]

114. Hajitou, A.; Trepel, M.; Lilley, C.E.; Soghomonyan, S.; Alauddin, M.M.; Marini, F.C., 3rd; Restel, B.H.; Ozawa, M.G.; Moya, C.A.; Rangel, R.; et al. A hybrid vector for ligand-directed tumor targeting and molecular imaging. Cell 2006, 125, 385-398. [CrossRef] [PubMed]

115. Hajitou, A.; Rangel, R.; Trepel, M.; Soghomonyan, S.; Gelovani, J.G.; Alauddin, M.M.; Pasqualini, R.; Arap, W. Design and construction of targeted AAVP vectors for mammalian cell transduction. Nat. Protoc. 2007, 2, 523-531. [CrossRef] [PubMed]

116. Suwan, K.; Yata, T.; Waramit, S.; Przystal, J.M.; Stoneham, C.A.; Bentayebi, K.; Asavarut, P.; Chongchai, A.; Pothachareon, P.; Lee, K.Y.; et al. Next-generation of targeted AAVP vectors for systemic transgene delivery against cancer. Proc. Natl. Acad. Sci. USA 2019, 116, 18571-18577. [CrossRef] [PubMed]

117. Yata, T.; Lee, K.Y.; Dharakul, T.; Songsivilai, S.; Bismarck, A.; Mintz, P.J.; Hajitou, A. Hybrid nanomaterial complexes for advanced phage-guided gene delivery. Mol. Ther. Nucleic Acids 2014, 3, e185. [CrossRef] [PubMed]

118. Stoneham, C.A.; Hollinshead, M.; Hajitou, A. Clathrin-mediated endocytosis and subsequent endo-lysosomal trafficking of adeno-associated virus/phage. J. Biol. Chem. 2012, 287, 35849-35859. [CrossRef] [PubMed]

119. Hajitou, A. Targeted systemic gene therapy and molecular imaging of cancer: Contribution of the vascular-targeted AAVP vector. Adv. Genet. 2010, 69, 65-82. [PubMed]

120. Dascal, N. The use of Xenopus oocytes for the study of ion channels. CRC Crit. Rev. Biochem. 1987, 22, 317-387. [CrossRef]

121. Clemencon, B.; Fine, M.; Schneider, P.; Hediger, M.A. Rapid method to express and purify human membrane protein using the Xenopus oocyte system for functional and low-resolution structural analysis. Meth. Enzymol. 2015, 556, 241-265.

122. Zeng, S.L.; Sudlow, L.C.; Berezin, M.Y. Using Xenopus oocytes in neurological disease drug discovery. Expert Opin. Drug Discov. 2020, 15, 39-52. [CrossRef]

123. Rothman, J.E.; Lenard, J. Membrane asymmetry. Science 1977, 195, 743-753. [CrossRef] [PubMed]

124. van Meer, G. Dynamic transbilayer lipid asymmetry. Cold Spring Harb. Perspect. Biol 2011, 3. [CrossRef] [PubMed]

125. Siontorou, C.G. Bilayer lipid membrane constructs: A strategic technology evaluation approach. In Advanced Bioelectronic Materials; Scrivener Publishing: Beverly, MA, USA, 2015.

126. Siontorou, C.G.; Nikoleli, G.P.; Nikolelis, D.P.; Karapetis, S.K. Artificial lipid membranes: Past, present, and future. Membranes 2017, 7, 38. [CrossRef] 
127. Rosilio, V. How can artificial lipid models mimic the complexity of molecule-membrane interactions. In Advances in Biomembranes and Lipid Self-Assembly; Academic Press: Cambridge, MA, USA, 2017; Volume 27, pp. 107-146.

128. Simons, K. Cell membranes: A subjective perspective. Biochim. Biophys. Acta 2016, 1858, $2569-2572$. [CrossRef] [PubMed]

129. Cornell, B.A.; Separovic, F. Membrane thickness and acyl chain length. Biochim. Biophys. Acta 1983, 733, $189-193$. [CrossRef]

130. Binder, H.; Lindblom, G. Charge-dependent translocation of the Trojan peptide penetratin across lipid membranes. Biophys. J. 2003, 85, 982-995. [CrossRef]

131. Afonin, S.; Frey, A.; Bayerl, S.; Fischer, D.; Wadhwani, P.; Weinkauf, S.; Ulrich, A.S. The cell-penetrating peptide TAT(48-60) induces a non-lamellar phase in DMPC membranes. Chemphyschem 2006, 7, 2134-2142. [CrossRef]

132. Lamaziere, A.; Wolf, C.; Lambert, O.; Chassaing, G.; Trugnan, G.; Ayala-Sanmartin, J. The homeodomain derived peptide Penetratin induces curvature of fluid membrane domains. PLoS ONE 2008, 3, e1938. [CrossRef]

133. Lamaziere, A.; Burlina, F.; Wolf, C.; Chassaing, G.; Trugnan, G.; Ayala-Sanmartin, J. Non-metabolic membrane tubulation and permeability induced by bioactive peptides. PLOS ONE 2007, 2, e201. [CrossRef]

134. Martin, S.R.; Schilstra, M.J. Circular dichroism and its application to the study of biomolecules. Methods Cell. Biol. 2008, 84, 263-293. [PubMed]

135. Hedegaard, S.F.; Derbas, M.S.; Lind, T.K.; Kasimova, M.R.; Christensen, M.V.; Michaelsen, M.H.; Campbell, R.A.; Jorgensen, L.; Franzyk, H.; Cardenas, M.; et al. Fluorophore labeling of a cell-penetrating peptide significantly alters the mode and degree of biomembrane interaction. Sci. Rep. 2018, 8, 6327. [CrossRef] [PubMed]

136. Marks, J.R.; Placone, J.; Hristova, K.; Wimley, W.C. Spontaneous membrane-translocating peptides by orthogonal high-throughput screening. J. Am. Chem. Soc. 2011, 133, 8995-9004. [CrossRef] [PubMed]

137. Melikov, K.; Hara, A.; Yamoah, K.; Zaitseva, E.; Zaitsev, E.; Chernomordik, L.V. Efficient entry of cell-penetrating peptide nona-arginine into adherent cells involves a transient increase in intracellular calcium. Biochem. J. 2015, 471, 221-230. [CrossRef]

138. Katz, M.; Ben-Shlush, I.; Kolusheva, S.; Jelinek, R. Rapid colorimetric screening of drug interaction and penetration through lipid barriers. Pharm. Res. 2006, 23, 580-588. [CrossRef]

139. Kolusheva, S.; Shahal, T.; Jelinek, R. Peptide-membrane interactions studied by a new phospholipid/polydiacetylene colorimetric vesicle assay. Biochemistry 2000, 39, 15851-15859. [CrossRef] [PubMed]

140. Grossmann, G.; Opekarova, M.; Malinsky, J.; Weig-Meckl, I.; Tanner, W. Membrane potential governs lateral segregation of plasma membrane proteins and lipids in yeast. EMBO J. 2007, 26, 1-8. [CrossRef]

141. Gurtovenko, A.A.; Vattulainen, I. Lipid transmembrane asymmetry and intrinsic membrane potential: Two sides of the same coin. J. Am. Chem. Soc. 2007, 129, 5358-5359. [CrossRef]

142. Moghal, M.M.R.; Islam, M.Z.; Sharmin, S.; Levadnyy, V.; Moniruzzaman, M.; Yamazaki, M. Continuous detection of entry of cell-penetrating peptide transportan 10 into single vesicles. Chem. Phys. Lipids 2018, 212, 120-129. [CrossRef]

143. Islam, M.Z.; Ariyama, H.; Alam, J.M.; Yamazaki, M. Entry of cell-penetrating peptide transportan 10 into a single vesicle by translocating across lipid membrane and its induced pores. Biochemistry 2014, 53, 386-396. [CrossRef]

144. Scott, R.E. Plasma membrane vesiculation: A new technique for isolation of plasma membranes. Science 1976, 194, 743-745. [CrossRef] [PubMed]

145. Charras, G.T.; Yarrow, J.C.; Horton, M.A.; Mahadevan, L.; Mitchison, T.J. Non-equilibration of hydrostatic pressure in blebbing cells. Nature 2005, 435, 365-369. [CrossRef] [PubMed]

146. Levental, K.R.; Levental, I. Giant plasma membrane vesicles: Models for understanding membrane organization. Curr. Top. Membr. 2015, 75, 25-57.

147. Fridriksson, E.K.; Shipkova, P.A.; Sheets, E.D.; Holowka, D.; Baird, B.; McLafferty, F.W. Quantitative analysis of phospholipids in functionally important membrane domains from RBL-2H3 mast cells using tandem high-resolution mass spectrometry. Biochemistry 1999, 38, 8056-8063. [CrossRef] [PubMed] 
148. Liu, Q.; Bi, C.; Li, J.; Liu, X.; Peng, R.; Jin, C.; Sun, Y.; Lyu, Y.; Liu, H.; Wang, H.; et al. Generating giant membrane vesicles from live cells with preserved cellular properties. Research 2019, 2019, 6523970. [CrossRef] [PubMed]

149. Terrettaz, S.; Ulrich, W.P.; Guerrini, R.; Verdini, A.; Vogel, H. Immunosensing by a synthetic ligand-gated ion channel financial support from the board of the swiss federal institutes of technology (SPP Minast. 7.06) is acknowledged. We thank G. Corradin for numerous discussions and J. Lakey for critical reading of the manuscript. Angew. Chem. Int. Ed. Engl. 2001, 40, 1740-1743. [PubMed]

150. Reid, L.M.; Verma, C.S.; Essex, J.W. The role of molecular simulations in understanding the mechanisms of cell-penetrating peptides. Drug Discov. Today 2019, 24, 1821-1835. [CrossRef]

(C) 2020 by the authors. Licensee MDPI, Basel, Switzerland. This article is an open access article distributed under the terms and conditions of the Creative Commons Attribution (CC BY) license (http://creativecommons.org/licenses/by/4.0/). 